ТЕОРІЯ ТА ІСТОРІЯ ДЕРЖАВИ І ПРАВА;

ІСТОРІЯ ПОЛІТИЧНИХ І ПРАВОВИХ УЧЕНЬ

УДК 342.5

DOI https://doi.org/10.32844/2618-1258.2020.6-2.1

РЕШЕТНЯК Н.Б.

\author{
СПЕЦИФІЧНІ РИСИ РЕАЛІЗАЦЇ̈ ЕКОНОМІЧНОЇ ФУНКЦЇ̈ \\ СУЧАСНИМИ ДЕРЖАВАМИ: МІЖДИСЦИПЛІНАРНИЙ ПІДХІД
}

\title{
SPECIFIC FEATURES OF IMPLEMENTATION OF ECONOMIC FUNCTION BY MODERN STATES: INTERDISCIPLINARY APPROACH
}

\begin{abstract}
У статті відзначено, що функціональний блок діяльності держави передбачає окремий економічний напрям, що безпосередньо охоплює реалізацію двох функцій: економічної та зовнішньоекономічної. 3 економічним напрямом діяльності держави пов'язана реалізація широкого спектра найрізноманітніших функцій (політична, соціальна, забезпечення законності тощо). Встановлено, що економічний напрям діяльності держави всередині країни передбачає насамперед регулювання сфери економічних відносин для створення умов щодо розвитку виробництва; організації виробництва на підставі визнання і захисту різних форм власності, підприємницької діяльності; прогнозування розвитку економіки. На зовнішньому рівні (за межами держави) економічна функція реалізується шляхом встановлення і підтримки торгово-економічних відносин з іноземними державами; розвитку ділового партнерства і співробітництва в економічній сфері з усіма державами, незалежно від їхнього державного та суспільного ладу, а також рівня розвитку; інтеграції у світову економіку. Акцентовано увагу на тому, що в сучасних умовах можна спостерігати тенденцію відходу від такої позиції. Такий відхід детермінований тим, що реалізація зовнішньоекономічної функції стикається з домінуванням політичної складової частини. Зауважено, що гіпертрофована політична функція може суттєвим чином домінувати над економічною функцією. Незважаючи на конституційні та законодавчі запобіжники із цього питання, держави від практики такого домінування не завжди відходять. Адже в Україні до таких запобіжників можна віднести частину 4 статті 13 Конституції України, де зафіксовано, що держава забезпечує захист прав усіх суб'єктів права власності і господарювання, соціальну спрямованість економіки. Усі суб'єкти права власності рівні перед законом. Або, наприклад, згідно із частиною 1 статті 15 Основного закону України, суспільне життя в Україні грунтується на засадах політичної, економічної й ідеологічної багатоманітності.

У статті сформульовано пропозиції щодо доповнення концепції національної безпеки в частині, що стосується сфери економіки (економічної безпеки), а саме створення механізму зацікавленості окремих уповноважених органів влади та їх посадових осіб у створенні ефективного механізму реалізації національних інтересів держави у процесі участі в зовнішньоекономічній діяльності, зокрема й укладення окремих угод на міжнародному рівні.

Зроблено висновок про те, що економічна функція сучасної держави виступає як єдиний комплекс економічного напряму діяльності держави, що реалізується в межах як внутрішньої, так і зовнішньої політики держави. Реалізація економічної функції суттєвим чином пересікається із широким спектром інших функцій, покла-
\end{abstract}

(C) РЕШЕТНЯК Н.Б. - кандидат економічних наук, доцент, доцент кафедри загальної економічної теорії (Національний технічний університет «Харківський політехнічний інститут») 
дених на державу: політичною, екологічною, оборонною, соціальною тощо. Крім того, економічна функція суттєвим чином пов'язана з гарантуванням економічної безпеки як складовою частиною національної безпеки. У зв'язку із цим концепція національної безпеки сучасної держави завжди повинна приділяти суттєву увагу питанням економічної безпеки, забезпечення національних інтересів у цій сфері, недопущення домінування політичної доцільності над справді національними інтересами в економічній сфері.

Ключові слова: функції держави, економічна функиія, економічна безпека, економіка держави, начіональна безпека, бюро економічної безпеки.

The article notes that the functional unit of the state provides a separate economic direction, which directly covers the implementation of two functions: economic and foreign economic. Hence, the economic direction of the state is associated with the implementation of a wide range of various functions (political, social, legality, etc.). It is established that the economic direction of the state within the country involves, first of all, the regulation of economic relations to create conditions for the development of production; organization of production on the basis of recognition and protection of various forms of ownership, business activities; forecasting economic development. At the external level (outside the state) the economic function is realized by establishing and maintaining trade and economic relations with foreign states; development of business partnership and cooperation in the economic sphere with all states, regardless of their state and social system, as well as the level of development; integration into the world economy. Emphasis is placed on the fact that in modern conditions we can observe a tendency to move away from this position. Such a departure is determined by the fact that the implementation of foreign economic function is faced with the dominance of the political component. It is noted that the hypertrophied political function can significantly dominate the economic function. Despite constitutional and legislative safeguards on this issue, states do not always deviate from the practice of such dominance. After all, in Ukraine, such safeguards include part 4 of Article 13 of the Constitution of Ukraine, which states that the state provides protection of the rights of all subjects of property rights and management, the social orientation of the economy. All subjects of property rights are equal before the law. Or, for example, according to Part 1 of Article 15 of the Basic Law of Ukraine, public life in Ukraine is based on the principles of political, economic and ideological diversity.

The article formulates proposals to supplement the concept of national security in the part related to the sphere of economy (economic security), namely the creation of a mechanism of interest of individual authorities and their officials in creating an effective mechanism for realizing national interests in foreign economic activity. including the conclusion of separate agreements at the international level.

It is concluded that the economic function of the modern state acts as a single set of economic activities of the state, which is implemented both within domestic and foreign policy. The implementation of the economic function significantly intersects with a wide range of other functions assigned to the state: political, environmental, defense, social, and so on. In addition, the economic function is essentially related to ensuring economic security as a component of national security. In this regard, the concept of national security of the modern state should always pay significant attention to issues of economic security, ensuring national interests in this area, preventing the dominance of political expediency over the truly national interests in the economic sphere.

Key words: functions of state, economic function, economic security, economy of state, national security, bureau of economic security.

Вступ. Сучасний період існування світової спільноти вказує на те, що економічні чинники виступають локомотивами його розвитку, розвитку окремих держави та їхніх об'єднань. Сучасна держава, на яку покладається виконання цілої низки функцій, завжди приділяє увагу реалізації економічної функції. Водночас така реалізація залежить від інтенсивності державного впливу на економіку, від ступеня залучення органів державної влади в економічні процеси. 
Необхідність дослідження питання про специфічні риси реалізації економічної функції сучасними державами зумовлена поширенням двох суперечливих тенденцій, які здебільшого знаходять свій прояв у межах діяльності сучасних держав: одна з них спрямована на безмежне включення економіки в так званий світовий економічний простір, що в деяких випадках може загрожувати втратою економічного суверенітету самою державою; друга тенденція спрямована на квотування участі національної економіки в зовнішньоекономічній діяльності, що передбачає допуск іноземних елементів тією мірою, яка сприяє досягненню національних цілей держави і не створює загроз національним інтересам. Щодо цього постає також питання про реалізацію національних інтересів у вказаній сфері та про гарантування національної безпеки, передусім такої іiї складової частини, як безпека економічна. До речі, відповідно до ч. 1 ст. 17 Конституції України, гарантування економічної безпеки є не лише найважливішою функцією держави, але і справою всього народу.

Постановка завдання. Метою статті є дослідження специфічних рис реалізації сучасними державами економічної функції в умовах глобальних перетворень, що здебільшого впливають на стан, якість та ефективність їі реалізації.

Результати дослідження. Попри прагнення держави мінімізувати свій вплив на економіку (наприклад, шляхом роздержавлення різних сфер, приватизації державних підприємств, відкриття ринку землі тощо), у деяких сферах держава в останній час навіть збільшила свої можливості. Наприклад, було здійснено налагодження реалізації господарської діяльності в армії. Так, відповідно до ст. 1 Закону України «Про господарську діяльність у Збройних Силах України», господарська діяльність у Збройних силах України (далі - ЗСУ) виступає специфічною діяльністю військових частин, різноманітних закладів, установ та організацій ЗСУ, пов'язана із забезпеченням їхньої повсякденної життєдіяльності та передбачає виконання робіт і надання послуг, ведення підсобного господарства, передачу в оренду рухомого та нерухомого військового майна (за винятком озброєння, боєприпасів, бойової та спеціальної техніки), виробництво продукції, у межах і порядку, визначених законодавчо. До такої господарської діяльності належить діяльність військових частин, різноманітних закладів, установ і організацій ЗСУ з оборонних закупівель, пов'язана із закупівлею товарів, робіт і послуг оборонного призначення за імпортом, яким в установленому законодавством порядку надані повноваження на право здійснення імпорту товарів військового призначення і товарів, які містять відомості, що становлять державну таємницю.

Безперечно, така діяльність має і відповідні обмеження, а також особливе спрямування та правовий режим реалізації. Ідеться, зокрема, про те, що господарська діяльність у ЗСУ може здійснюватися виключно з метою одержання додаткових джерел фінансування життєдіяльності військ (сил) для підтримання на належному рівні їхньої бойової та мобілізаційної готовності. Крім того, господарська діяльність у ЗСУ не повинна негативно позначатися на боєготовності й боєздатності всіх підрозділів. Не допускається залучення військовослужбовців до виробництва продукції, виконання робіт і надання послуг, не передбачених законодавством.

У зв'язку із цим нам убачається необхідним сформулювати пропозиції щодо доповнення концепції національної безпеки в частині, що стосується сфери економіки (економічної безпеки). Ідеться про створення механізму зацікавленості окремих уповноважених органів влади та їх посадових осіб у створенні ефективного механізму реалізації національних інтересів держави у процесі участі в зовнішньоекономічній діяльності, зокрема й укладення окремих угод на міжнародному рівні.

У державознавстві функції держави традиційно поділяються на зовнішні та внутрішні [2, с. 58]. Серед внутрішніх функцій однією з перших виокремлюють економічну функцію. У свою чергу, серед зовнішніх функцій виділяють економічну функцію держави, що реалізується в межах її зовнішньої політики. Ї̈і називають зовнішньоекономічною. 3 огляду на це, з погляду функціонального підходу є всі підстави для того, щоб говорити про наявність двох економічних функцій: одна реалізується всередині держави, інша - переважно поза іїі межами.

Функціональне спрямування в цій царині являє собою окремий напрям діяльності держави, пов'язаний з упорядкуванням економічних відносин, що здійснюється в межах усіх традиційних правових форм реалізації функцій держави загалом. Ідеться про правотворчу функцію, у межах якої створюється відповідна правова база для правового унормування основних економічних процесів, з урахуванням економічної самостійності суб’єктів господарювання.

Також економічна функція передбачає безпосереднє втілення в життя правових норм, пов'язаних з унормуванням економічних відносин. Це передбачає правозастосовну форму такої реалізації. Крім того, реалізація економічної функції здійснюється в межах контрольної, правоохоронної та деяких інших правових форм. 
Отже, функціональний блок діяльності держави передбачає окремий економічний напрям, що безпосередньо охоплюватиме реалізацію двох функцій: економічної та зовнішньоекономічної. Безперечно, з економічним напрямом діяльності держави пов'язана реалізація широкого спектра найрізноманітніших функцій (політична, соціальна, забезпечення законності тощо).

Економічний напрям діяльності держави всередині країни передбачає насамперед регулювання сфери економічних відносин для створення умов щодо розвитку виробництва; організації виробництва на підставі визнання і захисту різних форм власності, підприємницької діяльності; прогнозування розвитку економіки. На зовнішньому рівні (за межами держави) економічна функція реалізується шляхом встановлення і підтримки торгово-економічних відносин 3 іноземними державами; розвитку ділового партнерства і співробітництва в економічній сфері 3 усіма державами, незалежно від їхнього державного та суспільного ладу, а також рівня розвитку; інтеграції у світову економіку.

Водночас у сучасних умовах можна спостерігати тенденцію відходу від такої позиції. Такий відхід детермінований тим, що реалізація зовнішньоекономічної функції стикається 3 домінуванням політичної складової частини. Водночас гіпертрофована політична функція може суттєвим чином домінувати над економічною функцією. Незважаючи на конституційні та законодавчі запобіжники із цього питання, держави від практики такого домінування не завжди відходять. Наприклад, в Україні до таких запобіжників можна віднести ч. 4 ст. 13 Конституції України, де зафіксовано, що держава забезпечує захист прав усіх суб'єктів права власності і господарювання, соціальну спрямованість економіки. Усі суб'єкти права власності рівні перед законом. Або, наприклад, згідно із ч. 1 ст. 15 Основного закону України, суспільне життя в Україні грунтується на засадах політичної, економічної й ідеологічної багатоманітності.

Друга половина XX ст. характеризується тим, що в розвинених державах світу як у доктрині, так і в державотворчій практиці в межах їхнього функціонального аспекту почала виокремлюватися економічна функція. Із практичного погляду це означає, що держава тим чи іншим чином втручається в економіку, прагне визначати темпи ії зростання, встановлює правові й інші межі між окремими ії галузями. Виникнення державного сектора економіки зумовлює наявність державної власності і державного управління підприємствами й організаціями. Щодо цього можуть навіть виникати ситуації, за яких держава стає найбільшим «підприємцем».

Держава також може відігравати роль найпотужнішого банкіра, що зосередив у своїх руках більшу масу позичкового капіталу. Сучасна держава здатна прогнозувати і гнучко регулювати економічні процеси в масштабі всієї країни. Водночас варто враховувати і те, що економічна функція держави набуває властивостей антикризового спрямування, що в комплексі впливає на створення соціально орієнтованої ринкової економіки, зокрема й шляхом урахування і погодження інтересів виробників і споживачів.

Економічна функція знаходить свій прояв у «виробництві та координації державою стратегічних напрямів розвитку економіки держави в оптимальному режимі». Економічна діяльність сучасної держави полягає в державному впливі на економічне життя суспільства загалом, що виражається: по-перше, у формуванні бюджету та контролі за його витратами, по-друге, у створенні державних програм відповідно до масштабів соціального розвитку держави, по-третє, у фінансуванні програм наукових досліджень у цій сфері, по-четверте, у видачі субсидій та премій виробникам матеріальних благ для стимулювання виробництва. Саме тому Кабінетом Міністрів України ухвалено Прогноз економічного та соціального розвитку Україні на 2020-2023 pp. [1] та інші нормативно-правові акти.

В Україні на реалізації економічної функції завжди було, $є$ та буде зосереджено найпильнішу увагу не тільки посадових осіб державних структур, а й політиків, бізнесменів, громадських діячів, науковців, юристів, економістів та інших. Планування створення Бюро економічної безпеки (яке повинне послідовно замінити податкові структури) цілком логічне та яскраве тому підтвердження. Таке нововведення створить необхідність внесення змін до безлічі нормативно-правових актів. Серед яких можемо назвати Кодекс законів про працю України; Кодекс України про адміністративні правопорушення; Кримінальний кодекс України; Кримінальний процесуальний кодекс України; закони України «Про оперативно-розшукову діяльність», "Про військовий обов’язок і військову службу»; «Про пенсійне забезпечення осіб, звільнених з військової служби, та деяких інших осіб»; «Про основні засади здійснення державного фінансового контролю в Україні»; «Про організаційно-правові основи боротьби 3 організованою злочинністю»; «Про державний захист працівників суду і правоохоронних органів»; «Про забезпечення безпеки осіб, які беруть участь у кримінальному судочинстві»; «Про страхування» тощо. 
Планується, що створення такої структури, як Бюро економічної безпеки, буде сприяти ефективному здійсненню державою економічної функції шляхом налагодження партнерських відносин між бізнесом та контролюючими органами; ефективності дій єдиного правоохоронного органу в боротьбі зі злочинами у сфері економіки; підвищенню позиції України в рейтингу легкості ведення бізнесу Doing Business, що здійснюється експертами Світового банку.

Висновки. Отже, економічна функція сучасної держави виступає як єдиний комплекс економічного напряму діяльності держави, що реалізується в межах як внутрішньої, так і зовнішньої політики держави. Реалізація економічної функції суттєвим чином пересікається із широким спектром інших функцій, покладених на державу: політичною, екологічною, оборонною, соціальною тощо. Крім того, економічна функція суттєвим чином пов'язана 3 гарантуванням економічної безпеки як складовою частиною національної безпеки. У зв'язку із цим концепція національної безпеки сучасної держави завжди повинна приділяти суттєву увагу питанням економічної безпеки, забезпечення національних інтересів у цій сфері, недопущення домінування політичної доцільності над справді національними інтересами в економічній сфері.

\section{Список використаних джерел:}

1. Про схвалення Прогнозу економічного та соціального розвитку України : постанова Кабінету Міністрів України від 29 липня 2020 р. № 671. URL: https://zakon.rada.gov.ua/laws/ show/671-2020-\%D0\%BF\#Text (дата звернення: 27.01.2020).

2. Богуцький В.В., Григоренко Є.І., Журавель А.М. Оборонна функція сучасної держави: теоретико-правовий аспект : монографія. Харків : Юрайт, 2021. 224 с.

СТЕФАНЧИШЕН Р.В.

\section{ПРОБЛЕМИ БЕЗПЕКИ НА МОРІ (ТЕОРЕТИКО-ПРАВОВИЙ АНАЛІЗ)}

\section{PROBLEMS OF SAFETY AT SEA (THEORETICAL AND LEGAL ANALYSIS)}

Актуальність статті полягає в тому, що піратство, відоме 3 найдавніших часів, на жаль, процвітає й нині. Сучасне морське піратство $\epsilon$ різноманітним і багатоликим. Вивчення піратських нападів свідчить, що пірати діють великими й малими групами, використовують невеликі швидкісні судна, озброєні ножами й легкою вогнепальною зброєю. Звичайно вони наближаються до судна з корми й використовують довгі абордажні гаки для проникнення на борт. Варто також зазначити, що піратство завжди було спрямовано як проти окремих осіб, так і проти мореплавання загалом. Наголошено, що від дій піратів страждають майже всі учасники морської торгівлі: відправники вантажу й вантажоодержувачі - торговельні компанії, яким належить перевезений товар; перевізники - судноплавні компанії, яким належать судна; страхові компанії, що страхують судна і вантажі. 3'ясовано, що грабіж на морських шляхах відбувається, коли невелике судно з піратами наближається до великого торговельного або іншого корабля, що має команду, а іноді й пасажирів. Пірати піднімаються на борт судна, загрожуючи його мешканцям, відбирають у них особисті цінності й гроші (цей тип піратства характерний для акваторії Південно-Китайського моря). Цим займається переважно бідне населення прибережних районів, що здавна поєднує мореплавання й рибальство з морським пограбуванням. Нерідко жителі віддалених островів нападають на пропливаючі судна заради продовольства й сигарет, недоступних для них іншим шляхом. Визначено, що маючи за мету збагачення, пірати спрямовують свою злочинну діяльність не проти су- 